\title{
KARAKTERISTIK BERKAS PADA BEAM PORT TEMBUS DAN SINGGUNG REAKTOR KARTINI
}

\section{BEAM CHARACTERISTICS OF PIERCING AND TANGENTIAL BEAM PORTS OF KARTINI REACTOR}

\author{
Tegas Sutondo, Syarip \\ Pusat Sains dan Teknologi Akselerator, BATAN \\ JL. Babarsari, Kotak Pos 6101 ykbb, Yogyakarta 55281 \\ e-mail : tegas@batan.go.id; tegas_s@yahoo.com
}

Diterima 12 Pebruari 2014, diterima dalam bentuk perbaikan 21 Maret 2014, disetujui 2 Juni 2014

\begin{abstract}
ABSTRAK
KARAKTERISTIK BERKAS PADA BEAM PORT TEMBUS DAN SINGGUNG REAKTOR KARTINI. Telah dilakukan serangkaian perhitungan untuk mempelajari karakteristik berkas neutron dan foton gamma pada beam port tembus dan singgung menggunakan program MCNPX. Kegiatan ini terkait dengan rencana perancangan dan penyediaan fasilitas eksperimen PGNAA (Prompt Gamma Neutron Activation Analysis) menggunakan sumber neutron dari salah satu beam port pada reaktor Kartini yang masih belum dimanfaatkan. Hasil dari simulasi ini akan digunakan sebagai dasar dalam pemilihan beam port yang dipandang paling sesuai untuk digunakan, berdasarkan beberapa persyaratan yang ditetapkan, seperti karakteristik spektrum neutron pada bagian keluaran beam port, dsb. Hasil evaluasi menunjukkan beam port singgung memberikan karakteristik spektrum neutron yang lebih baik dibanding beam port tembus sesuai dengan kriteria yang dipersyaratkan. Dalam hal ini nilai rasio fluks neutron termal dan epitermal terhadap fluks neutron cepat pada bagian keluaran beam port masing-masing $\phi_{\mathrm{h}} / \phi_{\mathrm{r}}=3,086$ dan $\phi_{\mathrm{ep} i} \phi_{\mathrm{k}}=2,733$ yang lebih tinggi dibanding untuk beam port tembus yang nilainya $\phi_{\mathrm{h}} / \phi_{\mathrm{r}}=0,803$ dan $\phi_{\mathrm{ep}} \phi_{\phi}=0,625$.
\end{abstract}

Kata kunci: Karakteristik, berkas, beam port, reaktor, Kartini.

\section{ABSTRACT}

BEAM CHARACTERISTICS OF PIERCING AND TANGENTIAL BEAM PORTS OF KARTINI REACTOR. A series of calculation simulations, were carried out to assess the beam's characteristics of neutron and photon over both the piercing and the tangential beam ports. This work was performed in conjunction with the on going plans to design and provide the PGNAA (Prompt Gamma Neutron Activation Analysis) experimental facility, by using one of the still unutilized beam ports of Kartini reactor, as the neutron source. The results will be used to select the most suitable one of the two beam ports for the intended use, based on the prescribed requirements, such as the neutron spectral characteristics at the beam port's outlet, etc. The results indicate that the tangential beam port provides better characteristics of neutron spectrum over the piercing beam port in accordance with the prescribed criterion. In this case, the ratio of thermal and epithermal neutron fluxes over the fast neutron flux are $\phi_{\mathrm{h}} / \phi_{\mathrm{r}}=3.086$ and $\phi_{\mathrm{ep} i} \phi \mathrm{h}=2.733$ respectively which are higher than those of the piercing beam port's values i.e. $\phi_{\mathrm{h}} / \phi_{\mathrm{r}}=0,803$ and $\phi_{\mathrm{ep}} \mathrm{i} / \phi_{\mathrm{r}}=0.625$ respectively.

Keywords: Characteristics, beam, beam port, reactor, Kartini.

\section{PENDAHULUAN}

$\mathrm{M}$ etode NAA/PGNAA telah banyak diaplikasikan di bidang industri, untuk mengidentifikasi kandungan unsur-unsur pada suatu sampel/bahan, seperti pada industri tambang batubara (1), semen (2), beton (3) dll., untuk mengetahui kondisi/kualitas dari produk yang dihasilkan secara on-line. Dalam hal ini sumber neutron yang digunakan umumnya dalam bentuk isotop pemancar neutron seperti Cf ${ }^{252}$. Namun perkembangan terakhir juga telah diperkenalkan penggunaan sumber neutron dari akselerator/generator neutron, seiring telah berhasil dikembangkannya model generator neutron ukuran kecil yang portable (1).

Kegiatan ini adalah tahapan awal terkait dengan rencana pembuatan fasilitas eksperimen PGNAA pada reaktor Kartini, menggunakan sumber neutron yang yang berasal dari penyalur berkas (beam port) yang tersedia, 
yang masih belum dimanfaatkan, seperti beam port tembus (piercing) atau beam port singgung (tangential). Dalam hal ini perlu dipelajari tentang karakteristik spektrum dari berkas neutron maupun foton gamma dari kedua beam port tersebut, yang selanjutnya akan digunakan sebagai dasar untuk memilih atau menentukan salah satu dari kedua beam port tersebut yang paling sesuai untuk digunakan sebagai fasilitas eksperimen berdasarkan kriteria teknis yang dipersyaratkan. Untuk maksud tersebut, telah digunakan program MCNPX versi 2.6 .0 (4) dan model MCNP untuk reaktor TRIGA yang telah tersedia ${ }^{(5)}$ sebagai dasar dalam perhitungan tentang karakteristik spektrum dari berkas neutron maupun foton/gamma sepanjang kedua beam port tersebut.

\section{Diskripsi Beam port Tembus dan Singgung}

Reaktor Kartini memiliki beberapa fasilitas irradiasi dan empat buah penyalur berkas (beam port) seperti ditunjukkan pada Gambar 1.
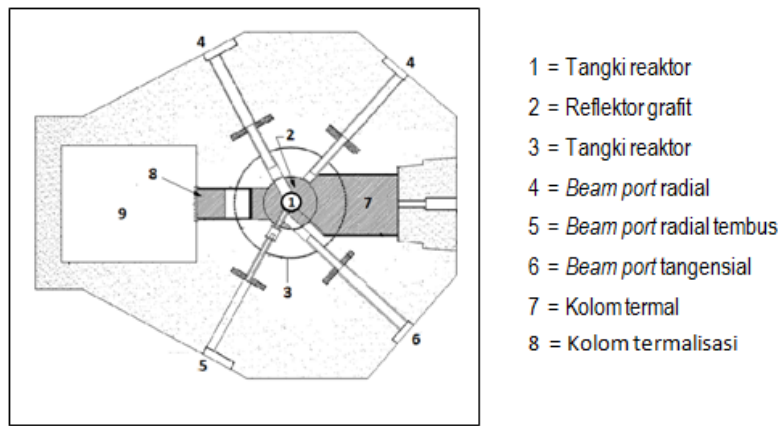

Gambar 1. Beberapa fasilitas irradiasi dan beam port pada reaktor Kartini.

Beam port tembus (BP1) menyalurkan berkas yang keluar dari permukaan bagian luar teras secara radial. Ujung beam port menembus bagian reflektor grafit hingga ke permukaan bagian dalam reflektor, sedang beam port singgung (BP2) dengan arah tangensial yang menyinggung bagian luar teras reaktor $(6,7,8)$.

BP2 terdiri dari bagian yang berada di dalam reflektor grafit yang berisi void dan bagian yang berada di luar reflektor grafit yang ujungnya berakhir pada bagian luar reflektor. Dinding dari kedua beam port tersebut terdiri dari 2 bagian utama, yaitu bagian dalam yang terbuat dari bahan aluminium (Al) dengan tebal $0.8 \mathrm{~cm}$ dan diameter $15.24 \mathrm{~cm}$ serta bagian luar yang terbuat dari baja dengan tebal $0.8 \mathrm{~cm}$ dan diameter $20.32 \mathrm{~cm}$. Gambar 2 dan 3 memperlihatkan uraian bagian dari kedua beam port yang berada di luar reflektor grafit secara lebih rinci.

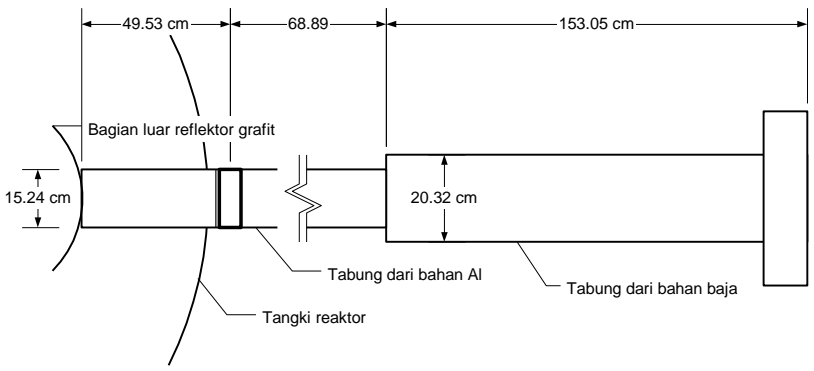

Gambar 2. Diskripsi beam port tembus.

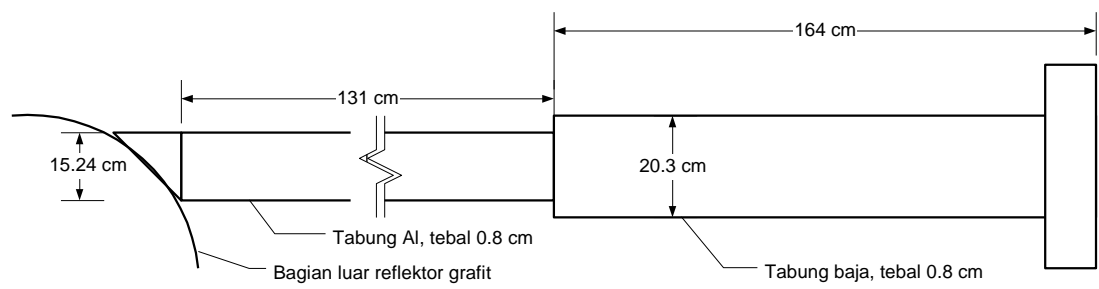

Gambar 3. Diskripsi beam port singgung (BP2). 


\section{METODOLOGI} berikut:

Secara ringkas untuk perhitungan karakteristik fluks dalam hal ini dilakukan melalui beberapa tahap sebagai

Mengingat dalam perhitungan MCNP, nilai fluks yang terhitung dinormalisasikan terhadap jumlah total partikel (source particle) ataupun per bobot (weight) dari partikelnya pada perhitungan kekritisan, maka untuk mendapatkan kuantitas yang sesuai dengan kondisi pengoperasian reaktor pada tingkat daya $100 \mathrm{~kW}$, perlu dilakukan peritungan Faktor Pengali Tally Flux (FM) berdasarkan persamaan (1)

$$
F M=\frac{P \times v}{Q \times k_{e f f}}
$$

dengan

$P=$ tingkat daya reaktor (Watt)

$U=$ jumlah neutron rerata yang dihasilkan per fissi

$Q=$ energi yang dihasilkan per fissi $=3,204 \times 10^{-11} \mathrm{~J}$

$k_{\text {eff }}=$ faktor multiplikasi neutron.

Dalam hal ini nilai $k_{\text {eff }}$ dan $\boldsymbol{u}$ diperleh dari perhitungan kekritisan untuk konfigurasi teras dan kondisi operasi saat ini. Selanjutnya dilakukan perhitungan tally fluks pada beberapa lokasi yang diinginkan dengan memasukkan nilai FM yang telah dihitung untuk tingkat daya $100 \mathrm{~kW}$. Perhitungan distribusi fluks sepanjang beam port dilakukan dengan cara segmentasi cell dan dilakukan melalui perhitungan kekritisan (KCODE). Dalam hal ini bisa digunakan file restart (runtpe) yang dihasilkan dari perhitungan sebelumnya. Demikian pula untuk perhitungan konversi fluks ke dosis paparan radiasi.

Bila tingkat ketelitian dari hasil yang diharapkan masih perlu diperbaiki, tahap ini diulangi dengan merubah parameter terkait.

\section{HASIL DAN PEMBAHASAN}

Dari hasil perhitungan kekritisan tahap pertama diperoleh nilai $u$ sebesar 2,4357 dan nilai $k_{\text {eff }}=1,0249$ sehingga berdasarkan persamaan (1) dapat ditentukan nilai faktor pengali FM untuk reaktor Kartini yang beroperasi pada tingkat daya nominal $100 \mathrm{~kW}$ sebesar

$$
F M=\frac{10^{5} \text { watt } \times 2.4357}{3.204 \times 10^{-11} \times 1.0249}=7.4174 \times 10^{15}
$$

Berdasarkan nilai $F M$ tersebut selanjutnya dapat digunakan untuk mentukan nilai fluks absolut pada lokasi yang diinginkan. Untuk perhitungan, fluks neutron dan foton gamma, spektrum berkas dievaluasi untuk beberapa interval energi mulai daerah energi termal $(0-0,5 \mathrm{eV})$; daerah epitermal $(0,5 \mathrm{eV}-0,1 \mathrm{MeV})$ dan daerah energi tinggi/cepat $(>0,1 \mathrm{MeV})$.

\section{Karakteristik Neutron Pada Beam port Tembus (BP1)}

Gambar 4 memperlihatkan ringkasan karakteristik neutron pada beberapa lokasi sepanjang BP1. Tampak bahwa pada bagian depan beam port fluks neutron termal paling tinggi, diikuti neutron epitermal dan cepat. Hal ini disebabkan adanya proses moderasi neutron dibagian reflektor grafit maupun air tangki reaktor.

Pada bagian luar tangki reaktor (bagian perisai beton) dimana proses moderasi sangat kecil, maka fraksi neutron cepat menjadi semakin meningkat dan akhirnya pada daerah ujung bagian luar, menjadi paling tinggi. Fluks neutron pada bagian luar untuk neutron termal, epitermal dan cepat masing-masing sebesar 1,8532 $\times 10^{8}$, $1,4425 \times 10^{8}$, dan $2,3076 \times 10^{8}\left[\mathrm{n} /\left(\mathrm{cm}^{2} \mathrm{~s}\right)\right]$.

Untuk mendapatkan informasi karakteristik spektrum yang lebih rinci pada daerah energi tinggi, maka dilakukan partisi terhadap daerah energi tinggi menjadi 5 interval energi yaitu dari $(0,1-3,0) \mathrm{MeV} ;(3,0-5,0) \mathrm{MeV}$; $(5,0-7,5) \mathrm{MeV} ;(7,5-10,0) \mathrm{MeV}$ dan $(10,0-20,0) \mathrm{MeV}$. Gambar 5 memperlihatkan spektrum fluks neutron sepanjang BP1 untuk ke lima interval energi pada daerah energi tinggi tersebut. 


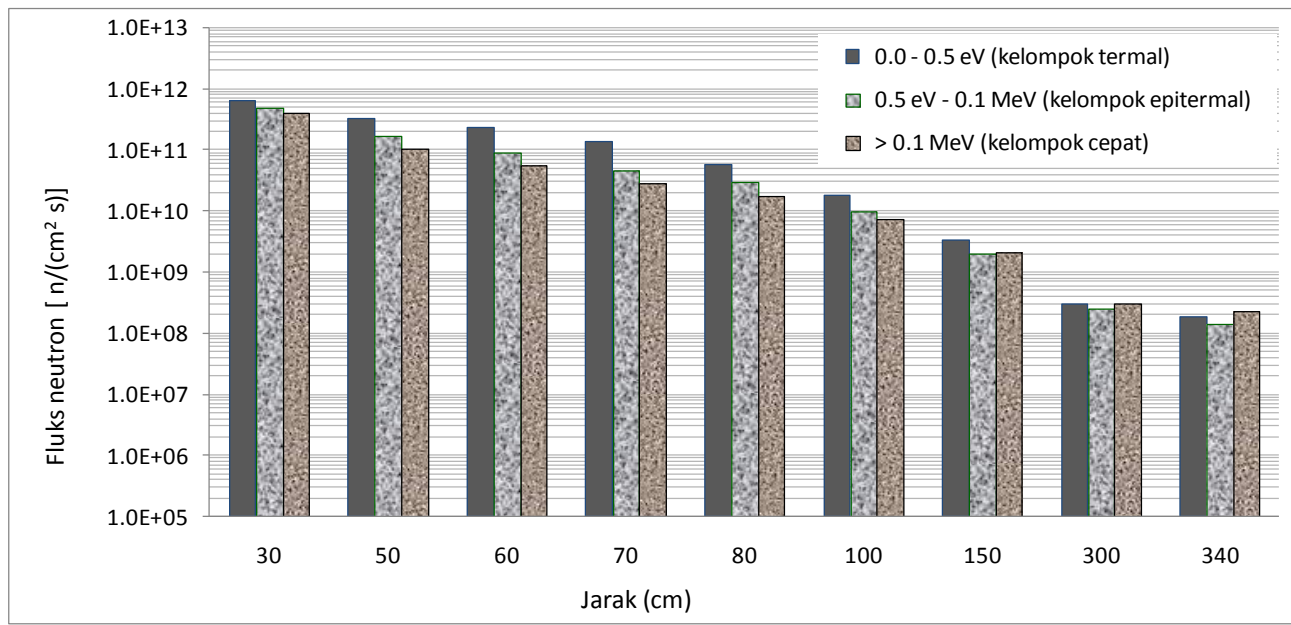

Gambar 4. Karakteristik fluks neutron pada BP1.

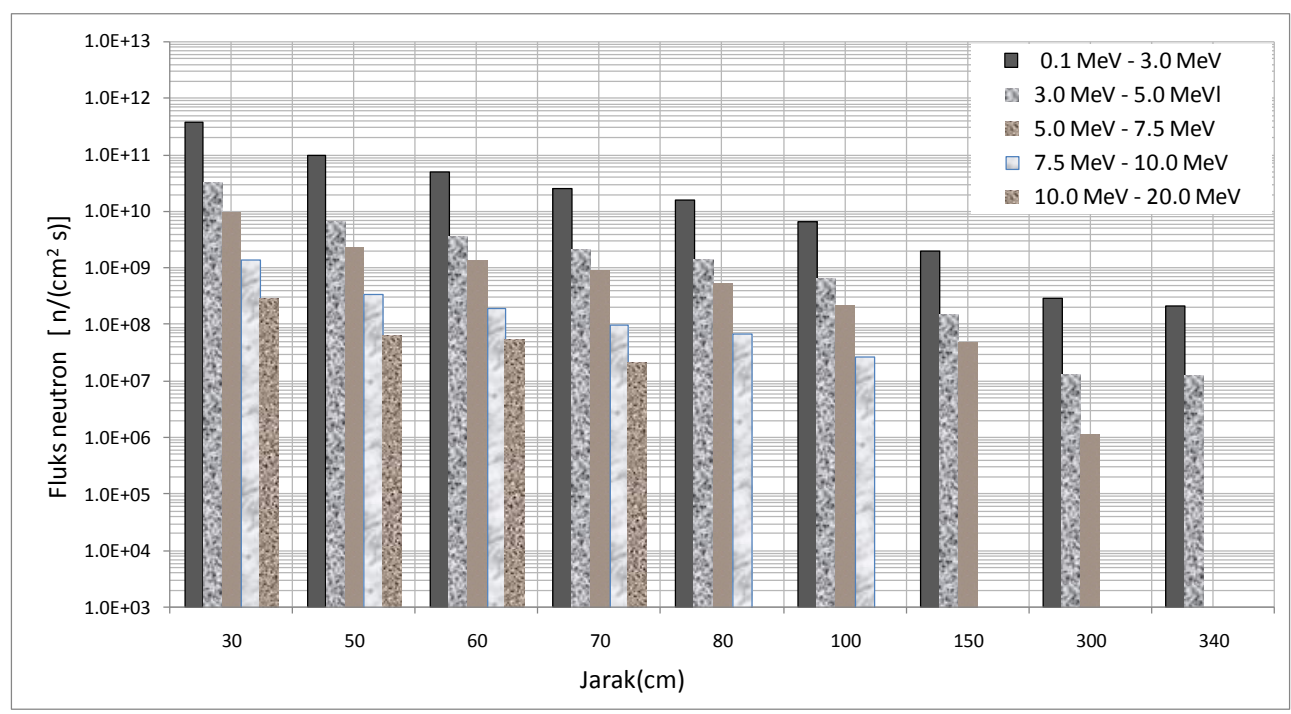

Gambar 5. Rincian karakteristik fluks neutron cepat sepanjang BP1.

Dari gambar tampak bahwa populasi neutron dengan energi antara 0,1 MeV hingga 3,0 MeV paling tinggi, diikuti dengan interval energi berikutnya, yang semakin kecil dengan meningkatnya energi. Pada jarak $80 \mathrm{~cm}$ neutron dengan energi di atas $10,0 \mathrm{MeV}$ sudah lenyap, diikuti oleh neutron dengan energi di atas $7,5 \mathrm{MeV}$ pada jarak $150 \mathrm{~cm}$ dan pada bagian luar hanya neutron dengan energi $<5,0 \mathrm{MeV}$ yang masih tampak.

\section{Karakteristik Neutron Pada Beam port Singgung (BP2)}

Karakteristik fluks neutron sepanjang BP2, ditunjukkan pada Gambar 6. Tampak bahwa sepanjang beam port, populasi neutron termal paling mendominasi diikuti oleh neutron epitermal kemudian neutron cepat. Pada daerah ujung hingga jarak sekitar 1 meter populasi neutron termal tampak mencolok terhadap yang lain, yang disebabkan pengaruh moderasi dari air pendingin, dan semakin kecil pada bagian perisai beton. Nilai fluks neutron termal, epitermal dan cepat pada bagian luar masing-masing sekitar 1,5274 $\times 10^{8}, 1,3523 \times 10^{8}$ dan $4,9488 \times 10^{7}$ $\left[\mathrm{n} /\left(\mathrm{cm}^{2} \mathrm{~s}\right)\right]$. 


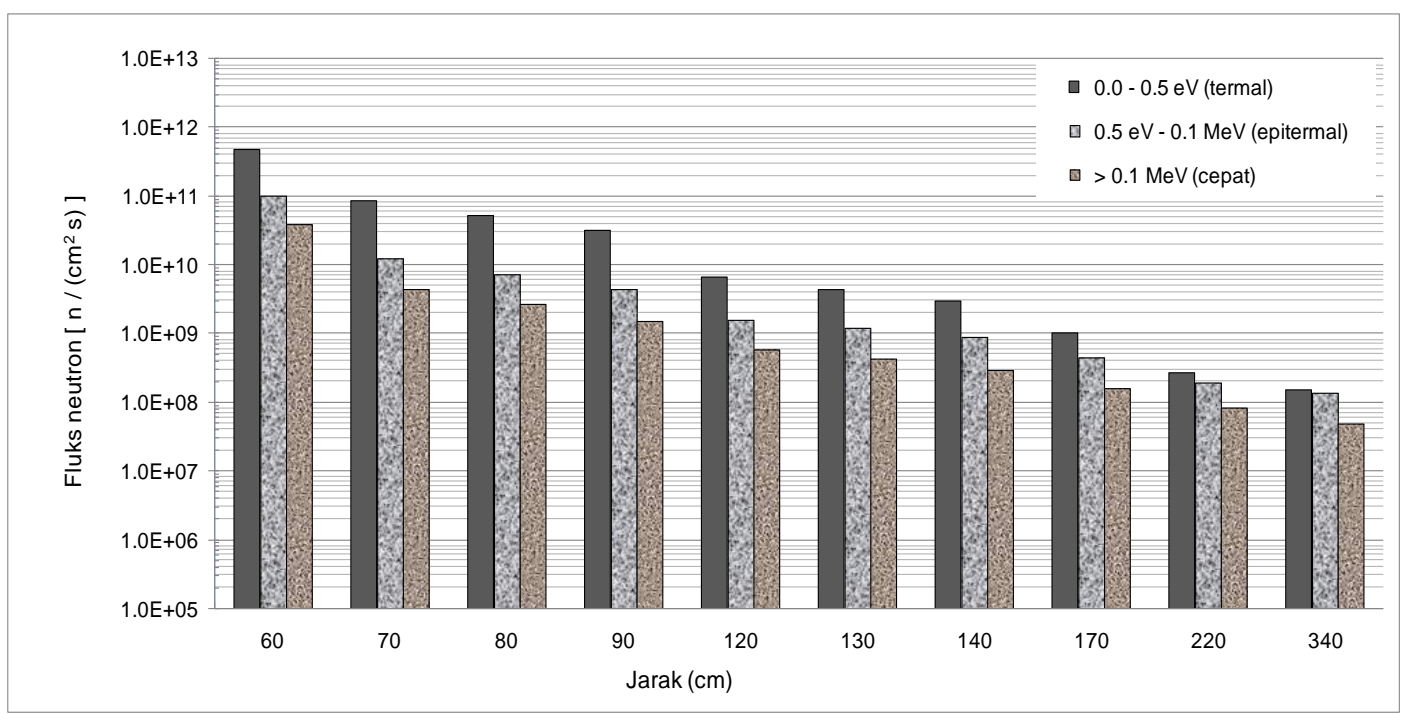

Gambar 6. Karakteristik fluks neutron pada BP2.

Rincian spectrum pada daerah energy tinggi ditunjukkan seperti pada Gambar 7, yang menunjukkan bahwa, neutron dengan energi antara 0,1 MeV hingga 3,0 MeV masih paling tinggi seperti halnya pada BP1. diikuti dengan interval energi berikutnya, yang semakin kecil dengan meningkatnya energi. Terlihat pula bahwa neutron dengan energi diatas $7,5 \mathrm{MeV}$ sudah lenyap pada jarak sekitar $120 \mathrm{~cm}$, diikuti oleh neutron dengan energi di atas $5,0 \mathrm{MeV}$ pada jarak $140 \mathrm{~cm}$ dan pada bagian luar hanya neutron dengan energi $<5,0 \mathrm{MeV}$ yang masih tampak. Lenyapnya neutron tersebut disebabkan beberapa faktor seperti proses moderasi, hamburan dan absorpsi oleh material di sekitar beam port.

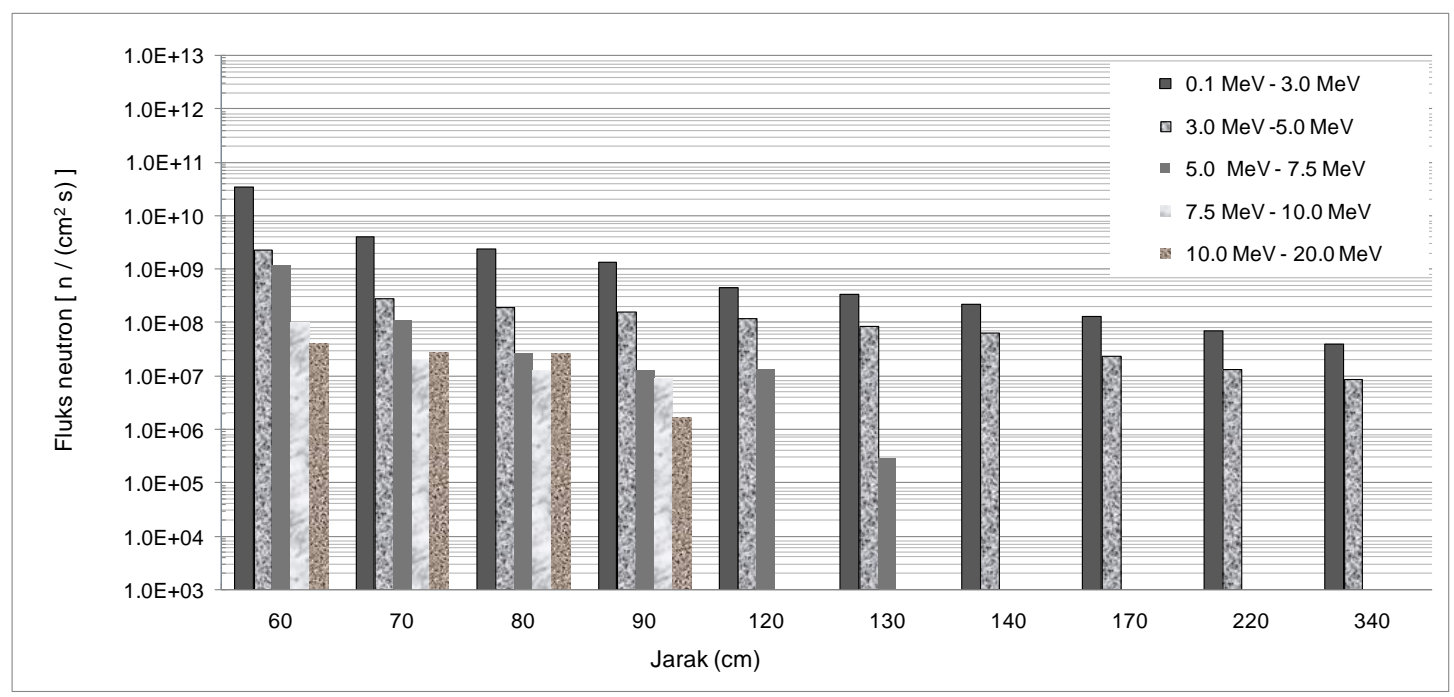

Gambar 7. Karakteristik fluks neutron cepat pada BP2.

\section{Karakteristik Foton Gamma Pada Beam port Tembus (BP1)}

Gambar 8 memperlihatkan karakteristik foton gamma sepanjang BP1. Dari grafik terlihat bahwa seluruh foton gamma yang dihasilkan memiliki energi di atas $0,5 \mathrm{MeV}$, dimana foton dengan energi di atas $0,1 \mathrm{MeV}$ terlihat paling dominan. Total fluks gamma pada bagian luar beam port sekitar $6.52 \times 10^{8}\left[\right.$ foton $\left./\left(\mathrm{cm}^{2} \mathrm{~s}\right)\right]$. 


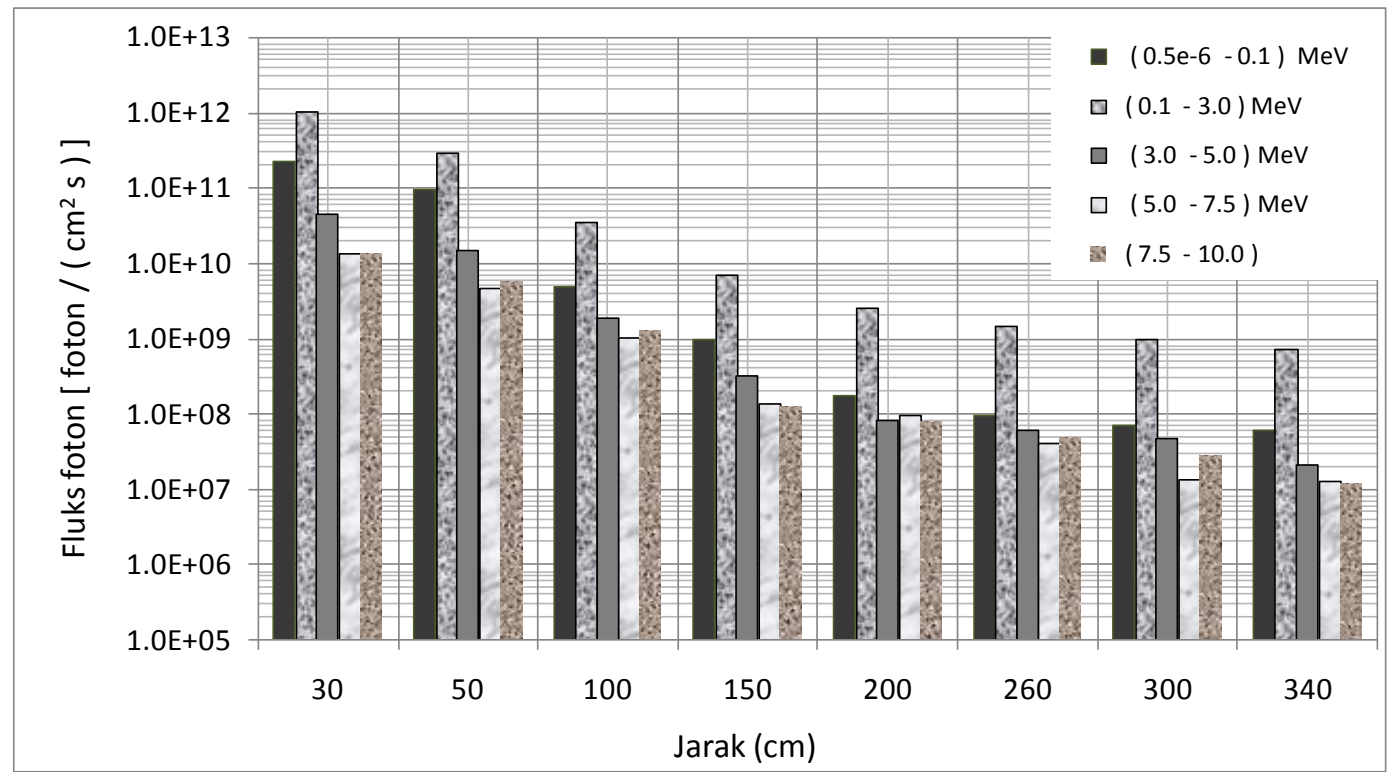

Gambar 8. Karakteristik foton gamma pada BP1.

\section{Karakteristik Foton Gamma Pada Beam port Singgung (BP2)}

Gambar 9 memperlihatkan karakteristik foton gamma sepanjang BP2. Seperti hal nya pada BP1, energi foton seluruhnya diatas $0,5 \mathrm{eV}$ dan foton dengan energi antara $0,1 \mathrm{MeV}-3,0 \mathrm{MeV}$ paling mendominasi. Total fluks foton gamma pada bagian luar sekitar 1,94 ×108 [foton $\left./\left(\mathrm{cm}^{2} \mathrm{~s}\right)\right]$.

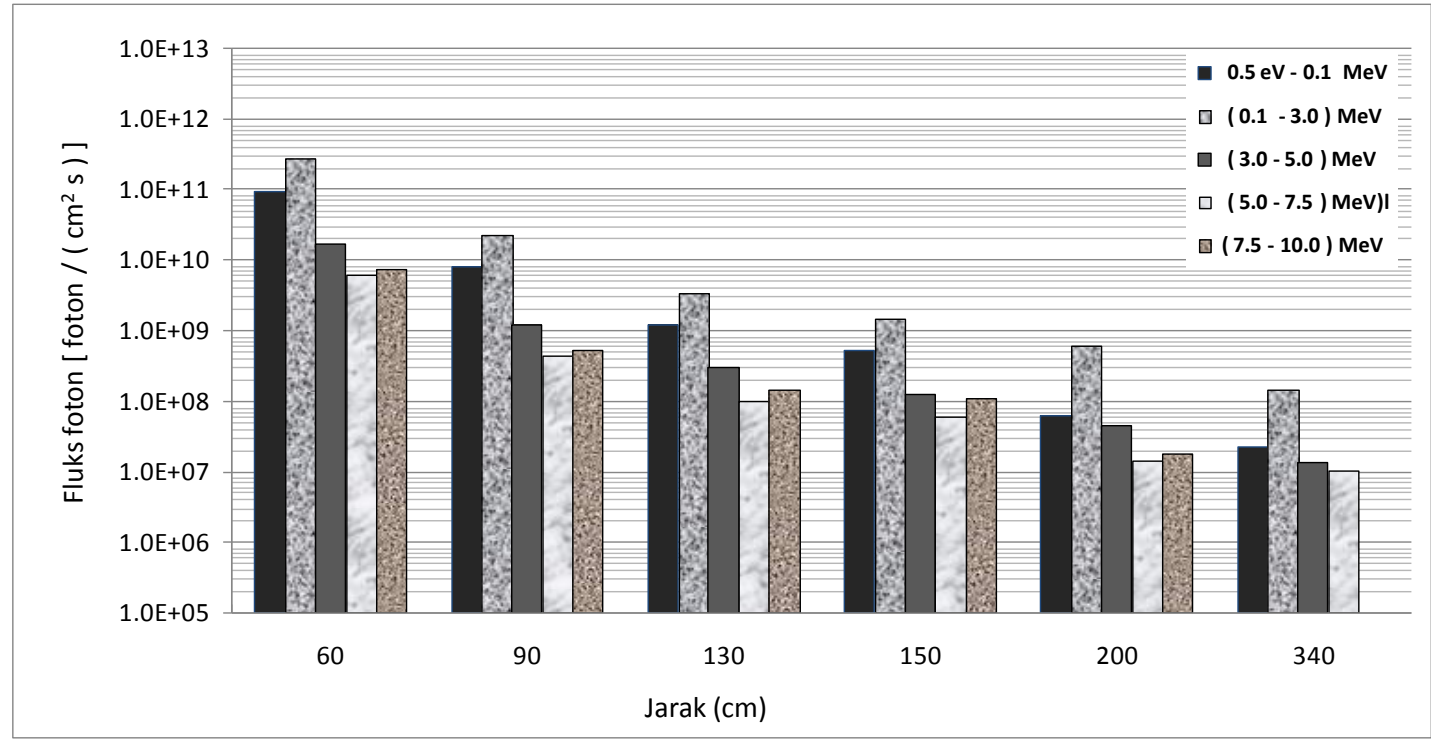

Gambar 9. Spektrum foton gamma sepanjang BP2.

\section{Dosis Paparan Radiasi}

Gambar 10 memperlihatkan dosis paparan radiasi pada bagian ujung dan bagian luar dari kedua beam port. Secara umum terlihat bahwa untuk kedua beam port tersebut paparan radiasi dari neutron paling dominan dibanding foton gamma. 


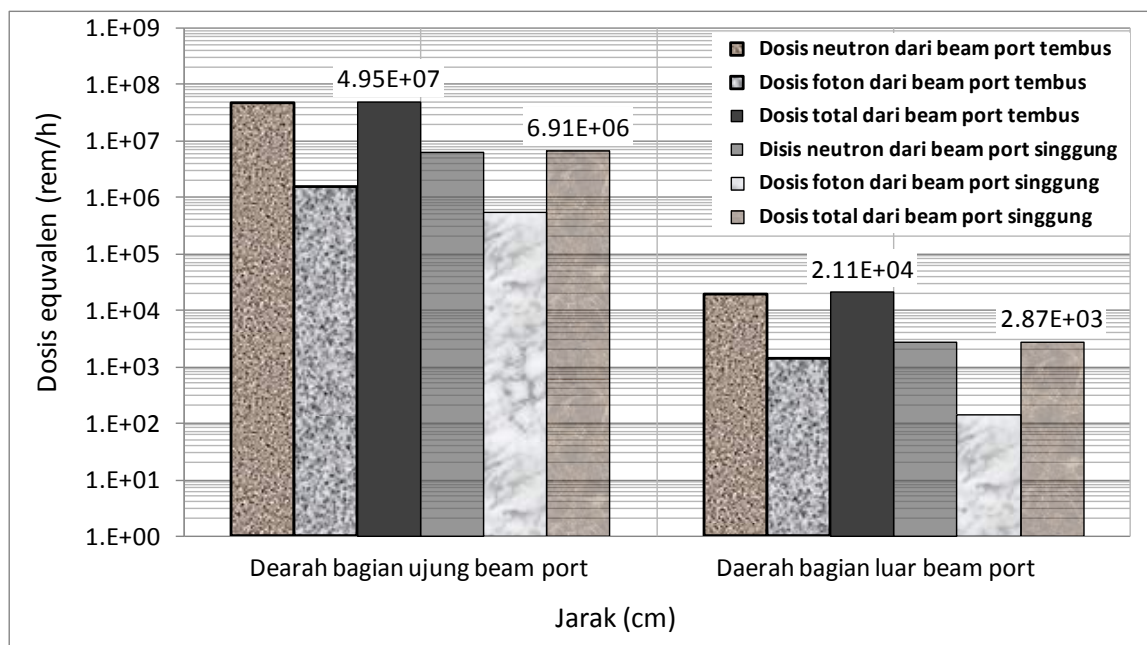

Gambar 10. Dosis paparan radiasi pada daerah ujung dan luar beam port.

Ringkasan hasil perhitungan fluks neutron $\left[\mathrm{n} /\left(\mathrm{cm}^{2} \mathrm{~s}\right)\right]$ dan foton gamma $\left[\mathrm{V} /\left(\mathrm{cm}^{2} \mathrm{~s}\right)\right]$ serta dosis paparan radiasi (rem/h) pada bagian luar beam port ditunjukkan pada Tabel 1.

Tabel 1. Ringkasan Hasil Perhitungan Karakteristik Fluks Neutron.

\begin{tabular}{lll}
\hline Parameter & BP1 & BP2 \\
\hline Fluks neutron termal $\left(\phi_{\mathrm{h}}\right)$ & $1,8532 \times 10^{8}$ & $1,5274 \times 10^{8}$ \\
\hline Fluks neutron epitermal $\left(\phi_{\text {epi }}\right)$ & $1,4425 \times 10^{8}$ & $1,3523 \times 10^{8}$ \\
\hline Fluks neutron cepat $\left(\phi_{\mathrm{t}}\right)$ & $2,3076 \times 10^{8}$ & $4,9488 \times 10^{7}$ \\
\hline Fluks neutron total $\left(\phi_{\mathrm{t}}\right)$ & $5,6033 \times 10^{8}$ & $3,3746 \times 10^{8}$ \\
\hline Rasio $\left(\phi_{\mathrm{th}} / \phi_{\mathrm{t}}\right)$ & 0,803 & 3,086 \\
\hline Rasio $\left(\phi_{\mathrm{ep}} / \phi_{\mathrm{t}}\right)$ & 0,625 & 2,733 \\
\hline Fluks foton gamma $($ total $)$ & $8,36 \times 10^{8}$ & $1,94 \times 10^{8}$ \\
\hline Dosis radiasi neutron $\left(D_{\mathrm{n}}\right)$ & $1,966 \times 10^{4}$ & $2,727 \times 10^{3}$ \\
\hline Dosis radiasi gamma $\left(D_{\mathrm{ph}}\right)$ & $1,447 \times 10^{3}$ & $1,402 \times 10^{2}$ \\
\hline Dosis radiasi total $\left(D_{\mathrm{t}}\right)$ & $2,111 \times 10^{4}$ & $2,867 \times 10^{3}$ \\
\hline
\end{tabular}

\section{KESIMPULAN}

Berdasarkan hasil perhitungan disimpulkan beberapa hal sebagai berikut:

Secara umum fluks pada beam port tembus baik neutron maupun foton lebih tinggi dibanding dengan pada beam port singgung. Karakteristik spektrum neutron pada beam port tembus bervariasi sepanjang beam port dimana pada bagian dalam neutron termal paling mendominasi, tetapi pada bagian luar neutron cepat paling mendominasi. Sedangkan untuk beam port singgung lebih stabil, dan menurun secara halus pada bagian luar, dengan neutron termal paling tinggi, diikuti dengan neutron epitermal dan neutron cepat paling rendah. Terkait dengan persyaratan sebagai fasilitas PGNAA, dimana aktivasi neutron didominasi oleh neutron berenergi rendah (termal dan epitermal), maka diperlukan berkas neutron yang memiliki karakteristik rasio fluks termal atau epitermal terhadap fluks cepat yang sebesar mungkin. Dari hasil perhitungan pada bagian luar beam port diperoleh rasio $\left(\phi_{\mathrm{th}} / \phi_{\mathrm{i}}\right)=0,803$ dan $\left(\phi_{\mathrm{ep}} / \phi_{i}\right)=0,625$ untuk BP1, sedang untuk BP2 rasio $\left(\phi_{\mathrm{th}} / \phi_{\mathrm{i}}\right)=3.086$ dan $\left(\phi_{\mathrm{ep}} / \phi_{\mathrm{i}}\right)=2,733$. Dengan demikian untuk perancangan fasilitas PGNAA maka beam port singgung lebih memenuhi kriteria yang dipersyaratkan dibanding beam port tembus. Demikian pula dari aspek radiologi, paparan radiasi pada bagian luar jauh lebih rendah sehingga lebih memudahkan dalam pemerisaian. 


\section{DAFTAR PUSTAKA}

1. S. SMITH, Nuclear Analyzer (using Neutron Generator), A case study at TVA Cumberland Plant, EPRI, Annual Technical Meeting, August 16-18, (2004) http://www.nwsassn.org/files/ tvacufcoalanalyzernwsa presentation1.pdf, diakses 04-02-2014

2. T.Q. QASIM, dkk., Analysis and Developments of PGNAA Installation at Al-Rashadiya Lafarge Cement Plant in Jordan, Proceedings of the 2011 Prosiding International Conference on Industrial Engineering and Operations Management, Kuala Lumpur, Malaysia, January 22 - 24- (2011) 1219 - 1224

3. I. E. STAMATELATOS, D. K. NANOPOULOS1, K. KASVIKI, F. TZIKA AND A. G. YOUTSOS, Non-Destructive Analysis Of Bulk Concrete Samples Using Prompt Gamma Neutron Activation Analysis: Preliminary Results, Institute of Nuclear Technology and Radiation Protection, NCSR 'Demokritos', Greece, $4^{\text {th }}$ International Conference on NDT, Helenic Society for NDT, (2007)

4. D. B. PELOWITZ, "MCNPXTM USER'S MANUAL", Version 2.6.0, April (2008) LA-CP-07-1473

5. P. I. YAZID, "TRIGA-MCNP", version 9, January (2006)

6. M.A. ZULQUARNAIN, DKK, Corrosion Induced Leakage In The Radial Beam Port Of The $3 \mathrm{Mw}$ Triga Mark-li Research Reactor Of Bangladesh, International Conference on Research Reactors: Safe Management and Effective Utilization, Rabat, Morocco, 14-18 November (2011)

7. DOKUMEN LAPORAN ANALISA KESELAMATAN (LAK) REAKTOR KARTINI REVISI VII, (2012)

8. GENERAL ATOMICS, "Mechanical Operation and Maintenance Manual," GA Document No. GA-A17054, General Atomics Project 2299, San Diego (1984) 